\title{
Extended Producer Responsibility for Waste Oil, E-Waste and End-of-Life Vehicles
}

\author{
Arner Asunción \\ Department of Applied Economics University of Zaragoza (Spain) \\ Email: aarner@unizar.es
}

\author{
Article History \\ Received: September 8, 2020 \\ Revised: October 11, 2020 \\ Accepted: October 18, 2020 \\ Published: October 22, 2020 \\ Copyright (c) 2020 ARPG \& \\ Author \\ This work is licensed under \\ the Creative Commons \\ Attribution International \\ (ㄷ) (1) CC BY: Creative \\ Commons Attribution License \\ 4.0
}

\begin{abstract}
This paper aims to explore the relationships of the performance of producer responsibility organizations (PROs) for waste oil, waste electrical and electronic equipment (WEEE), and end-of-life vehicles (ELV). The methodology consists in estimating the cointegration equations between the variables of lubricating oil production (SIG), electric and electronic equipment (EEE), and vehicle production (VP) using dynamic ordinary least squares (DOLS). Subsequently, elasticities are got based on estimates for Spain over the period 2007-2019 using quarterly data. The main results were that SIG and EEE were cointegrated variables. The elasticity of the SIG variable up to EEE was positive at 2, 4166. Additionally, the elasticity of the SIG variable up to VP was 2, 4050. However, SIG and VP are not cointegrated variables; subsequently, it was not a stable relationship between these variables. Results suggest it was because EPR was applied in WEEE PRO join with a deposit refund system (DRS); meanwhile, EPR in ELV PRO had been applied without subsidies to purchase cars.
\end{abstract}

Keywords: Extended producer responsibility; Waste oil; WEEE; ELV.

\section{Introduction}

In the European Union, extended producer responsibility (EPR) means a set of measures that include accepting returned products and the waste that remains after those products have been used, and the subsequent management of the waste and financial responsibility for such activities ${ }^{1}$. EPR also includes organizational responsibility and responsibility to contribute to waste prevention and the reusability and recyclability of products. These obligations can be fulfilled by producers of products individually or collectively. In the latter case, producers organize collective EPR systems, named PROs, which fulfill EPR obligations on behalf of producers. EPR for producers and PROs must meet minimum general requirements to reduce costs and boost performance and ensure an equal framework for all producers that avoid obstacles preventing the internal market's proper functioning.

The EPR is regulated by Directive 2008/98/EC and the EPR regimes for specific waste flows, such as those for WEEE, ELV, tires or batteries, and accumulators. Regarding waste oil, which in Europe applies to Directive 2008/98/EC, in Spain, Royal Decree 679/2006 on waste oils establishing EPR in managing waste oils. For this purpose, Spanish waste oil regulation set the ecological objectives of collecting $95 \%$ of the waste oils generated and valorizing $100 \%$ of the waste oils recovered in 2006 and regenerating $55 \%$ and $65 \%$ of the recovered oils in 2007 and 2008, respectively. The manufacturers of lubricants, to comply with the obligations arising from Royal Decree 679/2006, established in 2007 the Integrated Management System of Waste Oil (SIGAUS), by which the lubricant oil producers finance the management of waste oils through their contribution to SIGAUS of 0.06 euros per kilogram of the industrial oil they put on the market.

The EPR regime for WEEE is mandated by Directive 2002/96/EC of the European Parliament and the Council of 27 January 2003, which repealed Directive 2012/19/EU of the European Parliament and the Council of 4 July 2012 on WEEE. In Spain, these Directives are transposed by the Royal Decree 208/2005, of 25 February and Royal Decree 110/2015, of 20 February, on WEEE, respectively. The EEE producers have constituted different WEEE PROs, currently grouped in OfiRaee (AMBILAMP, Ecoasimelec, Ecofimática, Ecolum, Ecolec, Eco-Raee's, Ecotic and European Recycling Platform), as well as the PROs REINICIA Foundation Canaria for the Reciclaje and

\footnotetext{
${ }^{1}$ Directive (EU) 2018/851 of the European Parliament and the Council of 30 May 2018 modified the Waste Directive 2008/98/EC. Law 22/2011, 28 July, on Waste and Contaminated Soils transposed Directive 2008/98/EC.
} 
Development and SUNREUSE. Currently, OfiRaee coordinates the operation of the different WEEE PROs, allowing traceability of waste in all autonomous communities.

Royal Decree 20/2017, of 20 January, on ELV, updates the EPR regime for ELV, established by Directive 2000/53/EC of the European Parliament and the Council of 18 September 2000 on ELV, which transposed in Spain by Royal Decree 1383/2002 of 20 December on ELV. Vehicle producers are responsible for the vehicles they have placed on the market regarding decontamination and processing if they have carried out no prior disassembly of parts or components (Art 5 Royal Decree 20/2017). At the same time, avoiding double regulation and financing, waste generated over the life cycle of vehicles is mandated by Law 22/2011 of 28 July and the actual specific decrees for waste streams (tires, waste oil, batteries, and accumulators) ${ }^{2}$. The leading associations of vehicle manufacturers created the Spanish Association for the Environmental Treatment of ELV (SIGRAUTO) to collect and manage ELVs ${ }^{3}$.

Royal Decree 110/2015, on WEEE and Royal Decree 20/2017 on ELVs, was intended to transfer responsibility for managing waste oil in WEEE and ELV from the lubricant manufacturer to manufacturers of EEE and vehicles, respectively. Consequently, Royal Decree 110/2015 and Royal Decree 20/2017 established relationships between the PROs for waste oil, WEEE, and ELV. This paper aims to examine the relationships in the performance of the PROs mentioned above by estimating the cointegration equations among the variables SIG, EEE, and VP using dynamic ordinary least squares (DOLS). Subsequently, the elasticities between these variables are shown. The period considered is 2007-2019, and the data are quarterly.

According to the results, SIG and EEE were cointegrated variables; however, SIG and VP were not cointegrated variables. The elasticity of SIG up to EEE was positive at 2, 4156 and to VP at 2, 4050. Moreover, the variables of vehicle registration (VR) and SIG are cointegrated. The paper also suggests that results were a consequence that EPR was applied in WEEE PRO join with a deposit refund system (DRS); meanwhile, regarding EPR in ELV PRO, in last years, the automotive sector had not benefited from aid to purchase cars.

The rest of the paper is organized as follows. Section 2 presents a review of economic literature. Section 3 shows the main characteristics of the PROs for waste oil, WEEE, and ELV; meanwhile, section 4 refers to economic incentives. Sections 5 is about the methodology. Section 6 and 7 contain the results and conclusions, respectively.

\section{Review of Economic Literature}

Economic incentives play a crucial role in achieving waste prevention and waste management objectives, even when EPR is established. In the PROs studied, other economic incentive policies such as taxes or subsidies are applied along with EPR. Subsequently, the literature is initially reviewed regarding the efficiency of economic incentive policies and their application to EPR. The following section is about the literature review of the PROs for waste oil, WEEE, and ELV.

\subsection{The Efficiency of Economic Incentive Policies}

Various studies on market instruments, other than EPR, to reduce the amount of waste to be disposed of concluding that an SDR or combination of a product tax and a recycling subsidy is the most efficient policy (Dinan, 1993; Fullerton and Kinnaman, 1995; Fullerton and Wolverton, 2000; Palmer and Walls, 1997;1999; Sigman, 1995). Calcott and Walls (2005), point out that an SDR and a final elimination tax promote recycling design ${ }^{4}$. Some authors have discussed whether these policies are consistent with EPR. According to Palmer and Walls (1999), the SDR is consistent with EPR programs under perfect competition. Tsai et al. (2013), pointed out that even if the market is imperfectly competitive, the SDR is consistent with EPR. Regarding the recycled material standard (EMR), Walls (2006), notes that this policy is consistent with EPR regimes. If EMR is applied to the industry, rather than individually by producers, it confers flexibility and reduces costs (Palmer et al., 1995). Overall, the optimal recycled content of the entire supply chain may be a function of the parties' bargaining power to determine the sustainability level achieved by recycling (Geda et al., 2020).

According to Runkel (2003), under imperfect competition, EPR causes welfare losses because it does not consider imperfection due to producers' market power. Fleckinger and Glachant (2010), subsequently show that EPR individual programs are not an optimal solution, as each EPR program introduces a new risk of collusion and highlights the need to regulate the fees that finance PRO activities. Additionally, the product is relevant in the markets where EPR is established (cars, household appliances, food), and the quality of the product affects waste management costs. From the perspective of the organization of PROs, Kunz et al. (2018) point out that different PROs for a waste improve efficiency and reduce producer costs. However, collective systems also involve some

\footnotetext{
${ }^{2}$ Royal Decree 1619/2005 of 30 December regulates the management of out of use tires. Tire producers constitute SIGNUS (Integrated Management System of Tires Off-use) and TNU (Management of Used Tires). EPR regime for batteries and accumulators is outlined in Directive 2006/66/EC on batteries and accumulators (repeal Directive 91/157/CEE), which Royal Decree transposed 106/2008 of 1 February, on batteries and accumulators and the environmental management of their waste.

${ }^{3}$ Spanish Association of Automobile and Truck Manufacturers (ANFAC), National Association of Importers of Automobile, Truck, Bus and Motorcycle Importers (ANIACAM), currently integrated into ANFAC, Spanish Association of Scrap Yards and Automotive Recycling (AEDRA), and the Spanish Federation of Recovery and Recycling (FER).

${ }^{4}$ The green design has been defined as the process in which environmental attributes are considered for product design objectives Fullerton and $\mathrm{Wu}$ (1998). Policies for Green Design. Journal of Environmental Economics and Management, 36(2): 131-48. https://doi.org/10.1006/jeem.1998.1044. According to Eichner and Pethig (2001). Product Design and Efficient Management of Recycling and Waste Treatment. Journal of Environmental Economics and Management, 41(1): 109-34. https://doi.org/10.1006/jeem.2000.1126, a waste material's content increases recycling productivity and promotes efficient design.
} 
disadvantages. Some PROs compete in Europe to allocate WEEE to achieve economies of scale and even buy in the WEEE market to meet their obligations. These disadvantages can be solved by a central coordination mechanism (clearing house) that allocates waste for each PRO proportionately to its members' market share.

\subsection{Economic Research in PROs for Waste Oil WEEE, and ELV}

Assessing the efficiency of different policies to promote waste oil regeneration shows that an EMR is more efficient than a subsidy or a tax (Arner et al., 2005; Arner et al., 2006). Subsequently, it has been noted that SIGAUS constitutes an EMR applied to the lubricant sector (Arner, 2017a). Royal Decree 679 of 2 June 2006 on the management of industrial waste oils has been studied using a vector error correction model for the dynamic effects that the ecological objectives established have on the quantity of waste oils intended for regeneration and the price of base lubricating oils (Arner, 2017b). The existence of different PROs involved in the management of waste oil (SIGAUS, WEEE, ELV) has led to an increase in the efficiency of waste management, reducing the unit cost of management and driving the increase in the amount of waste oil collected and valued by the treatment of regeneration and combustion (Arner, 2018). This paper expands the study of competition in waste oil PRO to WEEE and ELV PRO.

The recycling of some materials contained in WEEE and ELV, such as iron, aluminum, and copper, has been analyzed from policies to promote recovery and recycling (Anderson and Spiegelman, 1977; Blomberg and Hellmer, 2000; Evans and Lewis, 2005; Fisher et al., 1972; Slade, 1980; Suslow, 1986). According to Andersson et al. (2019), recycling these materials in WEEE and ELV PROs works appropriately. Additionally, the recycling of some precious metals, such as gold, palladium, or silver, contained in WEEE is currently high. However, the recycling of these materials contained in ELV is restricted by the composition of the materials, the design for recycling legislation, capabilities, and business models of the recycling industry. In turn, the recycling of some smaller metals, gallium, and titanium, contained in both WEEE and ELV, requires, in the long term, both nationally and internationally, the development of new value chains. For Nakamura et al. (2012), the recycling of ferrous metals from ELV in uses other than this sector (open-loop recycling) is expected because the mixing of different types of metals in these residues determines that the quality of the resulting products does not reach the quality of the primary materials.

In the ELV PRO, it is common for EPR to apply in conjunction with other economic incentives, such as recycling fees (Netherlands) or a subsidy (Sweden). Mazzanti and Zoboli (2006), discuss how these instruments encourage innovation in design for recycling at different manufacturing stages, affecting economic agents from various industries. Besides, Forslind (2008) examines the relationship between the number of ELV recovered and the government subsidies in Sweden and concludes that the efficiency of EPR increases if combined with economic incentives to deliver ELV to an authorized center. Inghels et al. (2016), study the factors that determine the quantity and composition of authorized recycling centers for ELV to meet the objectives of Directive 2000/53/EC on ELV in Belgium, highlighting the need to increase innovation in plastic recovery.

WEEE PROs are studied from the perspective of reverse logistics options to increase the collection ratio and the expected benefits from life cycle analyses (Atasu and Van Wassenhove, 2012; Wang et al., 2015). Some authors consider the recycling ratios established to be arbitrary in this sector and respond to interest groups (Atasu et al., 2009; Atasu and Van Wassenhove, 2012). Chen et al. (2019), provide an instrument to the regulator setting WEEE recycling targets, considering that producer responsibility will incentivize the design that facilitates recycling products. Also, Esenduran et al. (2016), establishing a collection ratio in EPR programs in WEEE, including recycled products, discourages recycling. If e-waste recycling has a net profit, EPR does not necessarily have environmental and economic benefits (Esenduran et al., 2019). According to these authors, it largely depends on the competitive dynamics o e-waste acquisition and the added value generated by different parties involved in the processing of e-waste.

The comparison between individual responsibility systems (IRS) or collective responsibility systems (CRS) for WEEE is ambivalent, no definitive. Atasu and Subramanian (2012), point out that while IRS provides a reduction in recovery costs, because of the recycling design incentives it introduces, greater efficiency is achieved by CRS in the operating costs of these organizations. However, these results depend significantly on the degree of competition in the markets (product differentiation) and recovery costs. Toffel et al. (2008), comparing the efficiency of IRS and CRS, point out that while CRS achieves lower costs by obtaining economies of scale, they introduce fewer recycling design incentives.

\section{PROs for Waste Oil, WEEE and ELV}

In 2019, waste oils subject to different EPR regulations (Royal Decree 679/2006, Royal Decree 110/2015, Royal Decree 20/2017) represented $82.29 \%$ of the industrial oils marketed up to 354,435 tons, excluding exports of vehicles and electrical and electronic equipment. The remaining $17.21 \%$ corresponds to greases, marine and aviation oils, and process oils. Since it entered operation, SIGAUS has changed its market share, mainly since Royal Decree $110 / 2015$ and Royal Decree 20/2017 entered into force ${ }^{5}$. In 2020, the market share assumed by SIGAUS is $87.06 \%$, which includes $84.21 \%$ for industrial oils marketed by their commitments and $2.85 \%$ for the percentage of unidentified producers (Table 1).

\footnotetext{
${ }^{5}$ Market studies conducted by the independent consultant PwC.
} 
Table-1. Industrial oil market in 2020 without exports

\begin{tabular}{l|l}
\hline Adhering to SIGAUS & $\mathbf{8 4 . 2 1 \%}$ \\
\hline Free riders & $2.85 \%$ \\
\hline Market share assumed by SIGAUS & $87.06 \%$ \\
\hline Adhering to SIGPI* & $6.53 \%$ \\
\hline Automotive Import** & $0.52 \%$ \\
\hline Royal Decree 110/2015 WEEE & $0.66 \%$ \\
\hline Royal Decree 20/2017 ELV & $5.24 \%$ \\
\hline
\end{tabular}

* Integrated Independent Producer Management System.

**Imports for vehicles not included in RD 20/2017, not affiliated with any integrated management system.

Source: SIGAUS (2020b)

Simultaneously, SIGAUS carried out new actions to increase cover waste management with greater efficiency and flexibility. In 2016, SIGAUS established the variable payment of collections according to the geographical locations where they took place, assigning each Spanish municipality to one of 4 zones depending on its distance to the existing management centers and the volume of waste generated in the previous year, two variables of significant impact on the cost of collection (SIGAUS, 2018). Moreover, SIGAUS established additional compensation linked to the international price of lubricant bases (ICIS) to modulate financing according to this crucial indicator's evolution.

In 2017, new actions were expanded with the monthly update of the amounts paid following the evolution of the leading indicators of petroleum derivatives (ICIS, for lubricants, and PLATTS for fuel oils) and with the quarterly reviews of imbalances defined in the cost study, based on information provided by management companies on the purchase and sale of waste oil and sale of products from it. This linkage allows a continuous adaptation of financing to market variations, injecting more financing into the management industry at times of low demand for treated waste oil, or reducing it in periods of best sales.

The above measures led to a reduction in the average cost of managing waste oil (Figure 1), which between 2016 and 2018 was by $42.49 \%$, from $142 € /$ ton to $81.66 € /$ ton (SIGAUS, 2019). In 2019, it raised to $101 € /$ t because of the end of cycle 2013-2019 (SIGAUS, 2020b). Besides, new actions from SIGAUS also contributed to the recovery of the amount of lubricating oil placed on the market (Figure 2) and the amount of oil recovered through the regeneration and energy recovery (Figure 3). In turn, in 2019, all these variables decreased.

Regarding WEEE, the Ministry for Ecological Transition set the state and regional minimum annual separate collection targets, payable for domestic and professional WEEE, by the minimum target of $65 \%$ of the EEE weight placed in the three preceding market years (Figure 4$)^{6}$. That objective is transferred to each EEE PRO according to the market share of its associated producers ${ }^{7}$. The objective by weight of the EEE or WEEE, to avoid possible double financing, does not include removable batteries, which must be extracted for proper management. To calculate the recovery objectives, the treatments to which the waste oils contained in the WEEE are subjected. Besides, non-removable batteries and accumulators are to be included ${ }^{8}$.

Royal Decree 110/2015 establishes a single electronic information collection tool (Electronic Platform) in force since 2019, directly recording the data of the WEEE for collection and management, co-financed by the Ministry for Ecological Transition, which pays 55\% of this (through voluntary contributions from Regional Governments) and by the manufacturers who contribute the remaining $45 \%$. The electronic platform optimizes the effort of operators and avoids certain distortions generated by the multiplicity of platforms. In turn, the Collection Allocation Office (named OfiRaee), managed directly by the EEE producers, based on the information derived from the electronic platform, aims to make compulsory assignments throughout the nation to extended liability systems, based on territorial spaces, to collect and manage WEEE from local entities and distributors' collection facilities. Royal Decree 110/2015 also introduces an obligation for large distributors with a sales area of more than $400 \mathrm{~mm}$ to accept the collection of small WEEE (mobile phones) without the obligation to purchase an equivalent. These obligations are maintained in the sale of EEE through the Internet.

In Spain, the automotive sector is characterized by exported production of more than $80 \%$. Subsequently, EPR is applied to less than $20 \%$ of vehicle production (Figure 5). Since its foundation, SIGRAUTO has established a collection network that guarantees the vehicle's free delivery by the last user for its recovery and reuse treatment (Figure 6). It has organized a network of authorized treatment centers (ATCs), which reaches 569 in 2019 , and fragmentation facilities. In 2007, the entry fee for the General Vehicle Register of General Direction of Traffic was removed if the delivery is to an ATC, and it is not carried out by transfer to another country. Besides, since 2008, electronic decontaminated vehicle certificates have been regulated ${ }^{9}$.

\footnotetext{
${ }^{6}$ Royal Decree 208/2005 establishing the EPR of EEE producers set a separate WEEE collection target from $4 \mathrm{~kg}$ households/inhabitant/year and the obligation to achieve separate WEEE collection targets and recycling and recovery targets for each type of WEEE, differentiating 10 WEEE categories.

${ }^{7}$ Royal Decree 219/2013 of 22 March on restrictions on the use of certain hazardous substances in electrical and electronic equipment transposes Directive 2011/65/EU of the European Parliament and the Council of 8 June 2011 on restrictions on the use of certain hazardous substances in the electric and electronic equipment production.

${ }^{8}$ Battery producers and accumulators have adhered to different PROs (ECOPILAS, ERP, ECO/WEEE'S, ECOLEC) and, in another case, are part of SERNAUTO (Spanish Association of Automotive Equipment and Component Manufacturers).

9 Ministerial Order INT/624/2008, of 26 February, repeals Ministerial Order INT/249/2004, which established an obligation to present the certificate of destruction of the vehicle in an ATC.
} 
Royal Decree 20/2017 established that the total percentage of preparation for reuse and recovery should be at least $95 \%$ of the average weight per vehicle per year, and the total percentage of preparation for reuse and recycling shall be at least $85 \%$ of the average weight per vehicle per year (Figure 7). Moreover, the ATCs, from 1 February 2017, will recover for their preparation for reusing the market parts and components of vehicles involving at least $5 \%$ of the total weight of the vehicles they treat annually. From 1 January 2021, this percentage shall be $10 \%$, and from 1 January 2026, this percentage shall be $15 \%$ of the total weight of the vehicles they treat annually.

\section{Economic Incentives}

Law 16/2013 of 29 October includes a tax on HFC's consumption, PFC, and $\mathrm{SF}_{6}$ gases contained $\mathrm{WEEE}^{10}$. The tax is an incentive to deliver WEEE to an authorized manager because taxpayers can deduct the fees from the tax paid concerning fluorinated greenhouse gases that they prove to have delivered to authorized waste managers for destruction, recycling, or regeneration. Taxpayers must register their facilities in the Territorial Register of Greenhouse Fluorinated Gas Tax, which assists in registering WEEE producers ${ }^{11}$.

In Spain, the volume of treated ELV has mainly depended on the aid programs for the renovation of car parks ${ }^{12}$. According to SIGRAUTO (2020), in the year in which there was not a renovation program (PREVER 1997-2007, Innovative Vehicle, Green Vehicle (VIVE) 2008-2010 or 2000E 2009-2010), passenger cars treated falling approximately of 200,000 units. The PREVER Program established a deduction of the Registration Tax of 480.81 euros to purchase new and used vehicles. It supposed the increase of 3,34 million car sales and the saving of 4,2 million tons of $\mathrm{CO}_{2}$. The VIVE program financed up to 10,000 euros without interest, while the 2000E program granted 1,500 euros for the purchase of a new car or VO of fewer than five years. These programs came to finance and reward of 551,439 sales. Moreover, vehicle-renewal programs' existence or absence has significantly affected the average age of vehicle park $^{13}$.

Since 1 January 2008, the Registration Tax has been amended by applying tax rates based on official $\mathrm{CO}_{2}$ emissions and changing the heading of vehicles in which it falls from the previous criterion relating to the displacement of vehicles ${ }^{14}$. The Law 51/2002, of 27 December, reform of Law 39/1988, of 28 December, Regulator of Local Finances, established a tax of up to $75 \%$ on mechanical traction vehicles power-making tax benefits for municipalities, depending on the type of fuel that the vehicle consumes, and the characteristics of its engines and its impact on the environment.

Currently, due to decarbonization targets and air quality regulations in cities, the vehicle landscape is involved in a transition toward greater fuel efficiency and an increased percentage of alternative energy vehicles in the production mix and sales (ANFAC, 2020b). According to the Regulation (EU) 2019/631, setting binding emission reduction targets and vans for new registrations, from 1 January $2020, \mathrm{CO}_{2}$ emission will be with an average of 95 grams of $\mathrm{CO}_{2}$ per km traveled for passenger cars, reducing by $15 \%$ and $37.5 \%$ from 2025 and 2030, respectively (Figure 8). In Spain, using electric vehicles involves using renewable energy sources to improve the electricity system's overall efficiency.

The Incentive Programs for Efficient Vehicle Incentives (2010-2014), PIVE, and MOVELE (Table 2) consist of subsidies that are provided equally by the Industry Ministry and the manufacturer or point of sale $(2,000$ or 3,000 euros in the case of large families). These incentive programs have helped promote the acquisition of nearly 10,000 electric vehicles, avoiding over their lifetime the emission of 150,000 tons of $\mathrm{CO}_{2}$ and saving in that same period 300,000 barrels of oil. Since 2016, from the Vehicle Boost Strategy with Alternative Energies (2014-2020), aid has been aimed at the acquisition of alternative energy vehicles (MOVEA and MOVALT vehicles program), and the implementation of electric vehicle charging points (MOVALT infrastructure program) ${ }^{15}$. In 2019, MOVES Program funded regional governments to implement electric vehicle recharging infrastructure or purchase alternative vehicles ${ }^{16}$.

\footnotetext{
${ }^{10}$ Law 16/2013 of 29 October, set down specific environmental tax measures, and adopted other tax and financial measures.

${ }^{11}$ In 2014, the tax rates payable were 33\%, while in 2015 and 2016, they were 66\%. In 2017, the first year in which the tax is fully implemented, revenue increased by $26.67 \%$ compared with 2016 .

${ }^{12}$ National and local single-purchase aid, and state-level tax exemptions on vehicle registration and operation are standard instruments applied in cities with a high deployment of electric vehicles such as Amsterdam, Oslo, and Rotterdam-The Hague. In markets that have not addressed cost barriers in purchasing cars or property tax, such as Brussels or Madrid, they generally experience a slower deployment of electric vehicles (ICCT, 2020).

${ }^{13}$ In 2007, after several years with renovation programs, the vehicle park's average age was 8 years, reflecting car sales' good performance. Since 2012, the crisis's effects and the lack of effective park renovation programs supposed the vehicle park's average age increased to 10.5 years. In 2017, the economic recovery allowed for more purchases of new vehicles; however, the absence of renovation programs has led to the maintenance of most vehicles sold more than ten years ago, placing the average age of the park at 12 years (SIGRAUTO, 2019).

${ }^{14}$ Currently if the autonomous communities have not approved different ones, the enrollment tax rates set according to the official $\mathrm{CO}_{2}$ emissions of the vehicle are $0 \%$ if they are less than $120 \mathrm{~g} / \mathrm{km} ; 4.75 \%$ if they range from $120 \mathrm{~g} / \mathrm{km} \mathrm{to} 160 \mathrm{~g} / \mathrm{km}$; $9.75 \%$ if they range from $160 \mathrm{~g} / \mathrm{km}$ to $200 \mathrm{~g} / \mathrm{km}$ and $14.75 \%$ if emissions are more significant than $200 \mathrm{~g} / \mathrm{km}$ or for vehicles that are not required to measure their emissions.

${ }^{15}$ In 2016 and 2017, Mobility Boost Programs with Alternative Energy Vehicles (MOVEA), with a 16.6 million budget and 14.26 million, respectively. In 2018, MOVALT Vehicles Program, to incentivize alternative vehicles' acquisition, had a budget of 20 million euros, and the MOVALT Infrastructure Program (Incentive Program for implementing electric vehicle recharging infrastructure) had a budget of 20 million.

${ }^{16}$ Efficient and Sustainable Mobility Incentives Program (MOVES). The budget for this program was 45 million euros.
} 
Currently, MOVES II Program, funded by 100 million euros, provides subsidies for alternative energy vehicles, even electric vehicles ${ }^{17}$. Besides, Royal Decree-Law 25/2020 sets subsidies up to 250 million euros to purchase any vehicle, even gasoline or diesel vehicles. However, they will be CERO emissions, ECO, or C category for gasoline and diesel vehicles; in conventional vehicles, they must be A or B category in the IDAE Base Date of Carburates and $\mathrm{CO}_{2}$ emissions ${ }^{18}$. Also, car sellers apply a discount equal to the state aid up to 1,000 euros.

Table-2. Electric vehicle incentive programs

\begin{tabular}{l|l|l|l|l}
\hline Program & Date & Budget (M) & Records & Average age (years) \\
\hline PIVE & September 2012 & 75 & 72,227 & 17.29 \\
\hline PIVE 2 & January 2013 & 150 & 148,657 & 17.03 \\
\hline PIVE 3 & July 2013 & 70 & 68,488 & 16.91 \\
\hline PIVE 4 & October 2013 & 70 & 69,141 & 16.99 \\
\hline PIVE 5 & January 2014 & 175 & 171,356 & 16.69 \\
\hline PIVE 6 & June 2014 & 317 & 315,839 & 18.27 \\
\hline PIVE 7 & February 2015 & 39,5 & 36,646 & 16.75 \\
\hline PIVE 8 & May 2015 & 225 & 290,675 & 17.34 \\
\hline MOVELE 2014 & 6/6/2014 & 10 & 1,456 & -- \\
\hline MOVELE 2015 & $18 / 4 / 2015$ & 7 & 1,191 & --
\end{tabular}

\section{Data and Methods}

\subsection{Data Description}

The relationship between the PROs for waste oil, WEEE, and ELV is explored using the variable production because it is as a consequence of the responsibility for the waste oil in WEEE and ELV being transferred, respectively, from the lubricant manufacturer to the manufacturer of electrical and electronic equipment, as well as to the automobile manufacturer. Consequently, the variable used for the waste oil PRO is SIG: lubricating oil from associated producers in SIGAUS. Quarterly data were obtained from SIGAUS publications www.Sigaus.es/publicaciones (various years). For WEEE PRO, EEE is the variable used in https://ec.europa.eu/eurostat/data/database (manufacture of computer, electronic and optical products; manufacture of electrical equipment, volume index of production, base $100=2015$, seasonally and calendar adjusted data).

The variable used for automobile production is VP, in https://ec.europa.eu/eurostat/data/database (manufacture of motor vehicles, volume index of production, base $100=2015$, seasonally and calendar adjusted data). Moreover, the variable VR is used in http://aniacam.com/. In turn, the results have been compared using vehicle production (VP) and vehicle sales (VR).

\subsection{The Order of Integration of the Variables SIG, WEEE, and ELV}

The order of integration of variables is evaluated using the statistic Augmented-Dickey Fuller t-statistical (ADF) and the Schwarz information criterion ${ }^{19}$. Ho is the existence of a unit root in all cases ${ }^{20}$. The main conclusions are obtained using variables in second differences (Table 3). Subsequently, cointegration relationships between these variables are estimated. According to the results, the variables involved in the PROs for waste oil, WEEE, and ELV, in second differences, have a unit root. Therefore, the cointegration relationships between those variables are explored. In the end, the estimation of a cointegrating equation using DOLS in single time series settings for the variables SIG, WEEE, and ELV allows us to obtain the elasticities between cointegrated variables. In turn, that relationship is stable in the long term and not merely spurious.

\footnotetext{
${ }^{17}$ Royal Decree 569/2020, of 16 June, which regulates the incentives program for efficient and sustainable mobility.

${ }^{18}$ Royal Decree-Law 25/2020, of 3 July, approving urgent measures for economics and employment reactivation.

${ }_{19}$ According to Engle and Granger (1987), it is of interest to examine if a group of variables is cointegrated. It is because of their economic implications and if that relationship is stable in the long run. If there is a stationary linear combination of two or more non-stationary variables, that stationary linear combination is called a cointegration equation.

${ }^{20}$. The test for determining the order of integration of variables, Augmented-Dickey Fuller t-statistic (ADF), can be seen in Maddala and Kim,(1999)
} 
Table-3. Augmented-Dickey Fuller t-statistical AIC information criterion (second differences)

\begin{tabular}{l|l|l|l|l}
\hline Variables & Critical values & $\boldsymbol{t}$-statistics & $\boldsymbol{p}$-value \\
\hline SIG & $1 \%$ level & $-2,6225$ & $-6,0550$ & 0.0000 \\
\hline & $5 \%$ level & $-1,9490$ & & \\
\hline & $10 \%$ level & $-1,6118$ & & \\
\hline EEE & $1 \%$ level & $-2,6225$ & $-4,0021$ & 0.0002 \\
& $5 \%$ level & $-1,9490$ & & \\
& $10 \%$ level & $-1,6118$ & & 0.0011 \\
\hline VR & $1 \%$ level & $-3,6104$ & $-4,4160$ & \\
\hline & $5 \%$ level & $-2,9389$ & & \\
\hline VP & $10 \%$ level & $-2,6079$ & & 0.0003 \\
\hline & $1 \%$ level & $-3,6104$ & $-4,9033$ & \\
\hline & $5 \%$ level & $-2,9389$ & & \\
\hline
\end{tabular}

\subsection{Estimating Cointegration Equations for SIG, EEE, and VP Variables}

Subsequently, estimates of cointegration equations for EEE, VP, and SIG are shown, using DOLS. The number of delays and advances is chosen using the Akaike information criterion. Data are quarterly for the period 20072019. Variables in all equations are defined in logarithms.

The proposed cointegration function is for the variables SIG, EEE, and VP, considering responsibility for waste oil in WEEE and ELV is transferred from lubricating oil producer to EEE and vehicle producers as follows:

$$
\begin{aligned}
& \mathrm{SIG}=\mathrm{f}(\mathrm{EEE}) \\
& \mathrm{SIG}=\mathrm{f}(\mathrm{VP})
\end{aligned}
$$

Moreover, the expected sign of the coefficient of the EEE and VP variable will be positive in Equations 1 and 2.

Finally, the cointegrating equations for estimation, with $\mathrm{L}$ being the logarithmic notation of the variables, were as follows:

$$
\begin{aligned}
\mathrm{LSIG}_{\mathrm{t}} & =\beta_{1} \mathrm{LEEE}_{\mathrm{t}}+\mathrm{u}_{1 \mathrm{t}} \\
\mathrm{LSIG}_{\mathrm{t}} & =\beta_{2} \mathrm{VP}_{\mathrm{t}}+\mathrm{u}_{2 \mathrm{t}}
\end{aligned}
$$

where $u_{1 t}$ and $u_{2 t}$ constitute a white noise error term.

\subsection{Estimating Cointegration Equations for SIG and VR Variables}

This section shows the results of estimating cointegrating equations between SIG and VR variables. The estimate is made using DOLS, choosing the number of delays and advances using the Akaike information criterion. Data are quarterly for the period 2007-2019. Variables in all equations are defined in logarithms.

In this case, the proposed cointegration function for the variables SIG and VR; thus, the responsibility for waste oil in ELV is transferred from the lubricating oil producer to the vehicle producer as follows:

$$
\mathrm{SIG}=\mathrm{f}(\mathrm{VR})
$$

The expected sign of the coefficient of the VR variable will be positive in Equation 5.

Finally, according to the results, the cointegrating equation to estimate, with $\mathrm{L}$ being the logarithmic notation of the variables, follows:

$$
\mathrm{LVR}_{\mathrm{t}}=\alpha+\beta_{3} \mathrm{LSIG}_{\mathrm{t}}+\mathrm{u}_{3 \mathrm{t}}
$$

where $u_{3 t}$ constitutes a white noise error term.

\section{Results and Discussion}

\subsection{Cointegrating Equation 3 and 4}

The results of estimating Equations 3 and 4 (Table 4) were satisfactory enough concerning the model explanatory capacity $\left(\mathrm{R}^{2}\right)$. Moreover, the individual significance of $\beta_{1}$ and $\beta_{2}$ was accepted. In turn, there was a cointegrating equation for LSIG and LEE and LSIG and LVP. Subsequently, other characteristics of the error term are showed ${ }^{21}$. In Equations 3 and 4, under the Jarque-Bera statistic, the null hypothesis that the residues are distributed by a multivariate normal distribution was accepted at the significance level of 5\%. According to the statistic Q, the null hypothesis of the absence of autocorrelation, at the significance level of 5\%, is accepted in delay 3 in Equation 3. Besides, it was rejected in delay number 2 in Equation 4 at the same level of significance. Subsequently, cointegrating equations estimated was appropriate from estimation, although there was autocorrelation in the error term, particularly in Equation 4.

Finally, it was corroborated that the variables were effectively cointegrated through the statistical $t$ for the performance of the Engle-Granger test of cointegration, contrasting whether the residues in the cointegration equation were stationary. Moreover, the statistical $z$ for that test was used, including, in this case, autocorrelation in the error term. According to the Engle-Granger tau-statistic and z-statistic test, the Ho hypothesis was rejected, that the variables are not cointegrated, at the significance level of 5\% in Equation 3. Subsequently, the stochastic structure of variables was consistent enough. However, Ho was accepted in Equation 4. Consequently, that cointegrating relationship could not be stable in time and be merely spurious in Equation 4.

\footnotetext{
${ }^{21}$ Other characteristics of the error term were analyzed according to Novales,(2010) .
} 
Table-4. Estimates equations 3 and 4

\begin{tabular}{|c|c|c|c|}
\hline \multicolumn{4}{|c|}{ Dependent variable: LSIG $(9,10)$} \\
\hline Variable & Coefficient & t-statistic & p-value \\
\hline LEEE & 2,4156 & 927,8622 & 0,0000 \\
\hline \multicolumn{4}{|c|}{$\begin{array}{l}R^{2}=0,8169 \\
R^{2} \text { adjusted }=0,4842\end{array}$} \\
\hline \multirow{2}{*}{\multicolumn{2}{|c|}{ Jarque-Bera test }} & Statistical & P-value \\
\hline & & 0,9904 & 0,6094 \\
\hline \multicolumn{2}{|c|}{$\begin{array}{l}\text { Box-Pierce/Ljung-Box } \\
\text { Statistical Q }\end{array}$} & $\begin{array}{l}\text { Statistics/Delay } \\
7,8896 / 3\end{array}$ & $\begin{array}{l}\text { P-value } \\
0,0480\end{array}$ \\
\hline \multicolumn{2}{|c|}{$\begin{array}{l}\text { Engle-Granger } t \text { statistics } \\
\text { Engle-Granger } z \text { statistics }\end{array}$} & $\begin{array}{l}\text { Statistical } \\
-2,9010 \\
-13,0304\end{array}$ & $\begin{array}{l}\text { P-value } \\
0,0416 \\
0,0694\end{array}$ \\
\hline \multicolumn{4}{|c|}{ Dependent variable: LSIG $(10,9)$} \\
\hline Variable & Coefficient & t-statistic & p-value \\
\hline LPV & 2,4250 & 1046,7130 & 0,0000 \\
\hline \multicolumn{4}{|c|}{$\begin{array}{l}\mathrm{R}^{2}=0,9254 \\
\mathrm{R}^{2} \text { adjusted }=0,7898\end{array}$} \\
\hline \multirow{2}{*}{\multicolumn{2}{|c|}{ Jarque-Bera test }} & Statistical & $\mathrm{P}$-value \\
\hline & & 0,9854 & 0,6109 \\
\hline \multicolumn{2}{|c|}{$\begin{array}{l}\text { Box-Pierce/Ljung-Box } \\
\text { Q estadístico }\end{array}$} & $\begin{array}{l}\text { Statistics/Delay } \\
4,8278 / 1\end{array}$ & $\begin{array}{l}\text { P-value } \\
0,0280\end{array}$ \\
\hline \multicolumn{2}{|c|}{$\begin{array}{l}\text { Engle-Granger tau-statistic } \\
\text { Engle-Granger z-statistic }\end{array}$} & $\begin{array}{l}\text { Statistical } \\
-5,0070 \\
-46,0190\end{array}$ & $\begin{array}{l}\text { P-value } \\
0,0001 \\
0,0000\end{array}$ \\
\hline
\end{tabular}

Notes: Numbers in parentheses are the number of advances and delays, respectively.

The coefficient $\beta_{I}$ of 2, 4156 constituted the elasticity of LSIG to LEEE in Equation 3. Because using DOLS, $\beta_{I}$ was a long-term elasticity, with delays and advantages equal to 9 and 10. In the management of waste oil, because of the existence of different PROs, different actions have been established to manage waste oil more efficiently and flexibly (variable payment based on its distance to the refunds centers and the volume generated in the previous year, financing was monthly adapting to market evolution). These actions have meant the reduction of the unit cost of management from $142 € /$ ton to $81.66 € /$ ton. Moreover, 2015-2018 was accompanied by an increase in lubricant consumption and waste oils managed by SIGAUS between 2016-2018. In turn, all these variables decreased in 2019 as a result of the end of the cycle.

Besides, several actions have been introduced to facilitate more efficient waste management in WEEE PRO (OfiRaee, the electronic platform for WEEE management). Other actions have also been put in place to facilitate the collection of small WEEE (mobile phones) and the collection of WEEE in the sale of EEE via the Internet. In this case, the fully implemented greenhouse gas tax since 2017, and an incentive to deliver fluorinated gases to an authorized manager also influence the evolution of the WEEE collected. Besides, the amount collected from WEEE increased since 2015, as EEE on the market did, but it decreased in 2019.

In Equation 4, the coefficient $\beta_{2}$ of 2, 4250 was the elasticity of LSIG up to LVP. Moreover, $\beta_{2}$ constituted the long-term elasticity of LSIG up to LVP, with the number of delays and advantages of 10 and 9 . Since 2016 vehicle production decreased, except in 2019. Consequently, it occurs the opposite of lubricating oil. Last decade, vehicle production was linked exclusively to the promotion of less polluting vehicles, which estimated that low-emissions vehicles' acquisition reached up to 10.000 vehicles. However, diesel and gasoline vehicles had not received any subsidies. Moreover, since 2016, subsidies were not available for electric cars. Meanwhile, treated ELV increased since 2016, according to the more ambitious objectives of the recovery and recycling of ELV were established. Consequently, the absence of any economic incentive to vehicles manufacturer, opposite to WEEE, could determine that LSIG and LVP were not cointegrated variables. It was important because ELV PRO is responsible for the 5,24\% of waste oil and WEEE of the $0,66 \%$.

\subsection{Cointegrating Equation 6}

The estimating Equation 6 (Table 5) results were satisfactory concerning the model explanatory capacity $\left(\mathrm{R}^{2}\right)$. Moreover, the individual significance of all coefficients in the cointegrating equation was accepted. Regarding other characteristics of the error term, under the Jarque-Bera $t$ statistics, the residues were distributed by a multivariate normal distribution at the significance level of 5\%. However, according to the $\mathrm{Q}$ statistics, there was no autocorrelation in the error term at the significance level of 5\%. Besides, under the Engle-Granger tau-statistic and zstatistic test, the Ho hypothesis was rejected, that the variables were not cointegrated, at the significance level of 5\%. Consequently, LVR and LSIG variables were cointegrated. 
Table-5. Estimates Equation 6

\begin{tabular}{|c|c|c|c|}
\hline \multicolumn{4}{|c|}{ Dependent variable: $\operatorname{LVR}(8,9)$} \\
\hline Variable & Coefficient & t-statistic & p-value \\
\hline LSIG & 3,9012 & 3,8989 & 0,0030 \\
\hline $\mathrm{C}$ & $-31,2910$ & $-2,7930$ & 0,0190 \\
\hline \multicolumn{4}{|l|}{$\begin{array}{l}\mathrm{R}^{2}=0,9671 \\
\mathrm{R}^{2} \text { adjusted }=0,9048\end{array}$} \\
\hline \multirow[t]{2}{*}{ Jarque-Bera test } & & Statistical & P-value \\
\hline & & 4,2697 & 0,1182 \\
\hline $\begin{array}{l}\text { Box-Pierce/Ljung-Box } \\
\text { Q estadístico }\end{array}$ & & $\begin{array}{l}\text { Statistics/Delay } \\
14,709 / 9\end{array}$ & $\begin{array}{l}\text { P-value } \\
0,099\end{array}$ \\
\hline $\begin{array}{l}\text { Engle-Granger tau-stati } \\
\text { Engle-Granger z-statist }\end{array}$ & & $\begin{array}{l}\text { Statistical } \\
-1,0782 \\
-4,3354 \\
\end{array}$ & $\begin{array}{l}\text { P-value } \\
0,8872 \\
0,7741\end{array}$ \\
\hline
\end{tabular}

Notes: Numbers in parentheses are the number of advances and delays, respectively.

The coefficient $\beta_{3}$ of 3,9012 was the value of the elasticity of LVR up to LSIG in Equation 5. Moreover, using DOLS, $\beta_{3}$ constituted the long-term elasticity of the LVR up to LSIG variable, with the number of delays and advantages equal to 8 and 9, respectively. Besides, vehicle registration, as lubricating oil had increased since 2016, although it decreased in 2019. Since 2008, the Registration Tax has been amended by applying tax rates according to official $\mathrm{CO}_{2}$ emissions and the vehicle classification heading to promote less-polluting vehicles. In turn, the sales variable (VR) is less representative of EPR in ELV PRO than the production variable (VP) because it supposes $20 \%$ of vehicle production; besides, regional governments regulate the Registration Tax (Equation 6).

\section{Conclusions}

Since the beginning of the 21st century, according to European directives, systems of EPR have been established in Spain for waste oil, WEEE, ELV, tires, batteries, and accumulators. These systems have evolved towards the more ambitious collection, and treatment goals as previously established ones were achieved. In the same way, different measures have been applied to achieve a more efficient operation of PROs. The regulations have tended to avoid double regulation and financing of those wastes belonging to more than one PRO, being the producer responsible for all the waste generated by the consumption or use. Moreover, the producer is also responsible for using the materials obtained from the waste in the production processes.

RD 110/2015 and RD 20/2017 have set stable and positive interconnections between PROs for waste oil, WEEE, and ELV because the producer responsibility for the waste oils contained in the WEEE and ELV is transferred from the producer of waste oils to the manufacturer of electric and electronic equipment and vehicles, respectively. The main results were obtained regarding LEEE (production of electric and electronic equipment) and LSIG (production of lubricating oil) as variables cointegrated. The elasticity of the variable LSIG up to the variable LEEE was positive at 2,4166. Additionally, there was a cointegrating equation for LSIG and LVP (vehicle production), although they were not cointegrated variables. Besides, the elasticity of the LSIG variable up to the LVP was positive at 2,4050. Moreover, regarding ELV PRO, the variables LVR (vehicle registration) and LSIG were cointegrated. The elasticity of LVR up to the LSIG was 3,9012.

Efficiency gains in managing this waste have accompanied the existence of various PROs involved in the management of waste oil. These measures have meant the reduction of the unit cost of management and the increase of lubricant oil managed by SIGAUS from 2016 to 2018. However, it increased in 2019 because of the end of the cycle. Economic literature has said that a tax and a subsidy (DRS) combination constitutes the most efficient policy to achieve the recovery and recycling objectives. EPR in WEEE PRO is applied with a DRS because of a tax on greenhouse gases incentivizing the delivery of WEEE to an authorized manager. Besides, regarding ELV PRO, vehicle registration taxes are applied to account for vehicle emissions. However, VR only supposes $20 \%$ of the VP variable, and EPR affects overall production decisions. Besides, there are no subsidies for deregistering polluting vehicles and purchasing new low emissions vehicles. Consequently, the absence of any economic incentive to vehicles manufacturer, opposite to WEEE, could determine that LSIG and LVP were not cointegrated. Subsequently, the relationship between these variables was not stable, although WEEE PRO is responsible for the $0,66 \%$ of waste oil and ELV PRO of the 5,24\% of waste oil.

Results were based on the estimation of cointegrating equations between the variables involved in the functioning of PROs and, consequently, on long-term relationships. However, results were being autocorrelation in the error term. In addition, LSIG and LVP were not cointegrated variables. Subsequently, results may be changed because of aid for purchasing all types of vehicles, electric vehicles, diesel, or gasoline vehicles that have been restored in 2020. This fact is beneficial for car sales, increased treated vehicles, and improved electrical system efficiency.

\section{Acknowledgment}

I want to thank Jesús Mur (Department of Economic Analysis, Zaragoza University), who reviewed the paper. 
International Journal of Economics and Financial Research

Figure-1. Evolution of waste management costs (€/ton)

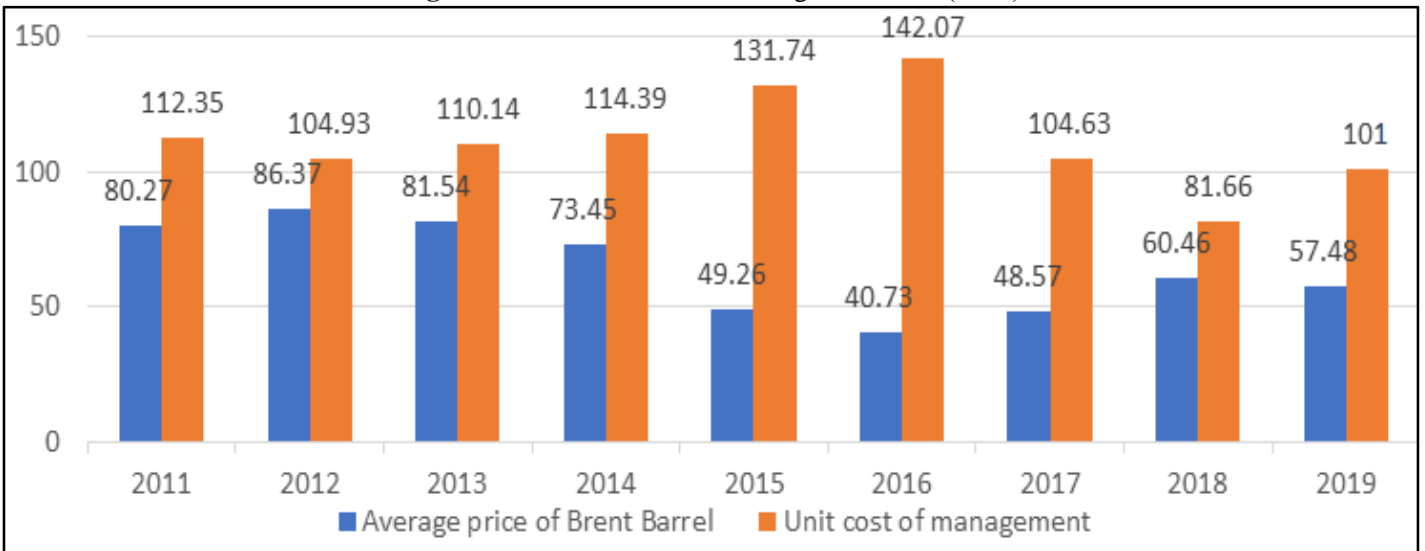

Source: SIGAUS (2020b), own source)

Figure-2. Evolution of industrial oil put on the market (tons)

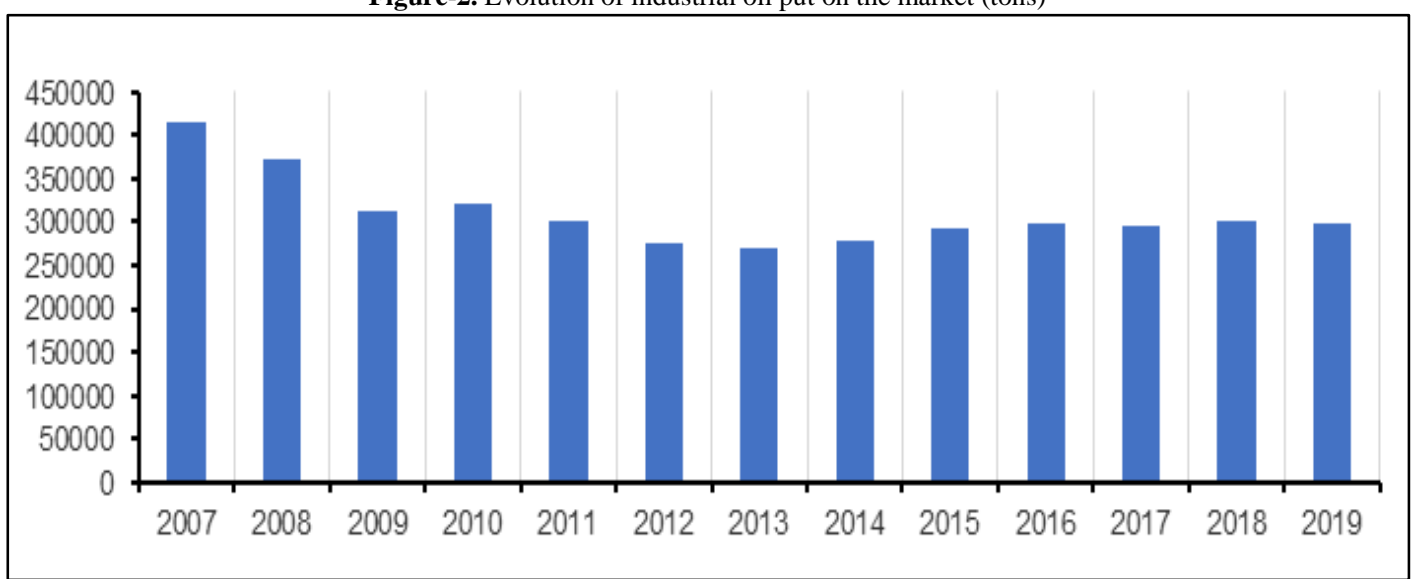

Source: SIGAUS (2020a)

Figure-3. Evolution of the quantities of waste oil undergoing different treatments

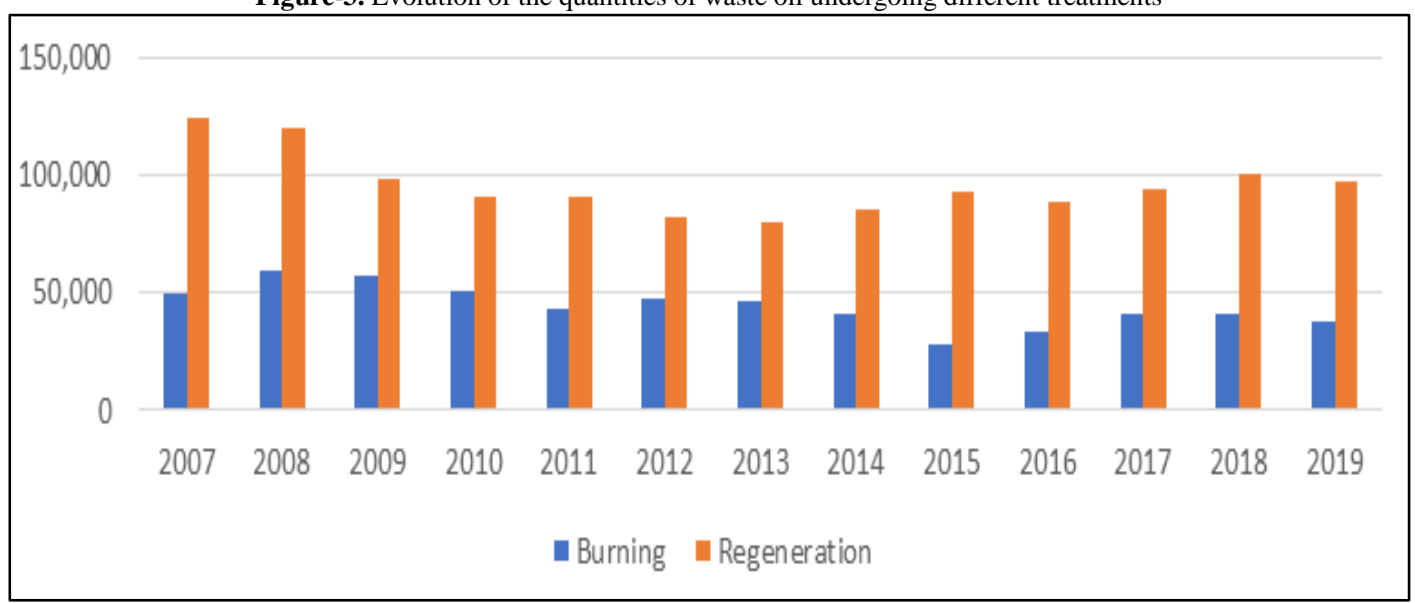

Source: SIGAUS (2020a)

Figure-4. EEE marketed and WEEE collection (tons)

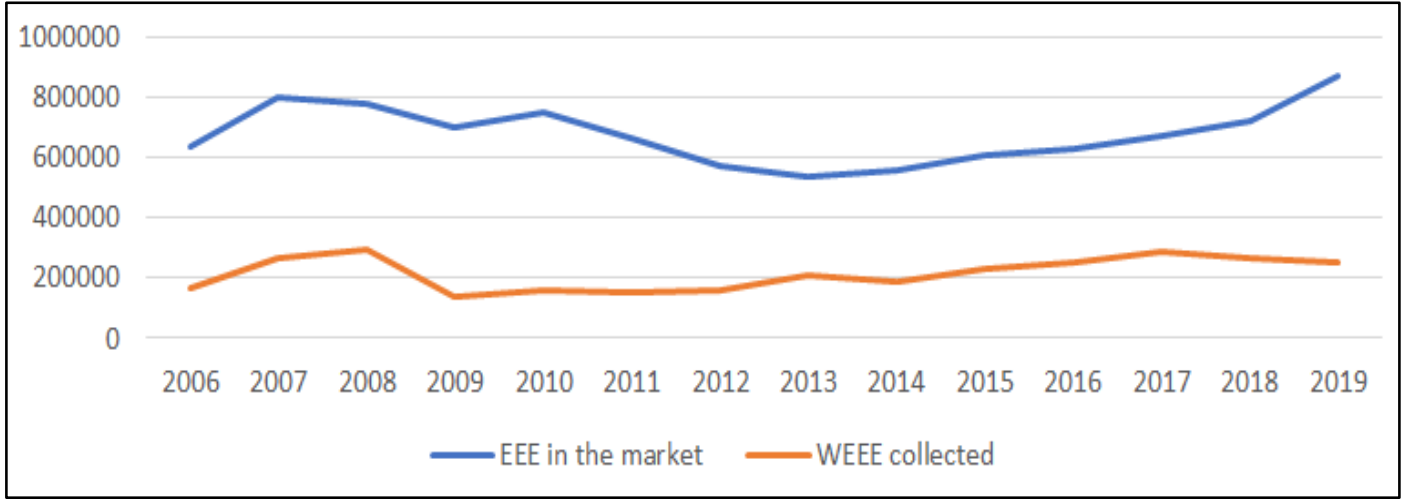

Source: Eurostat and information from the different integrated management system. 


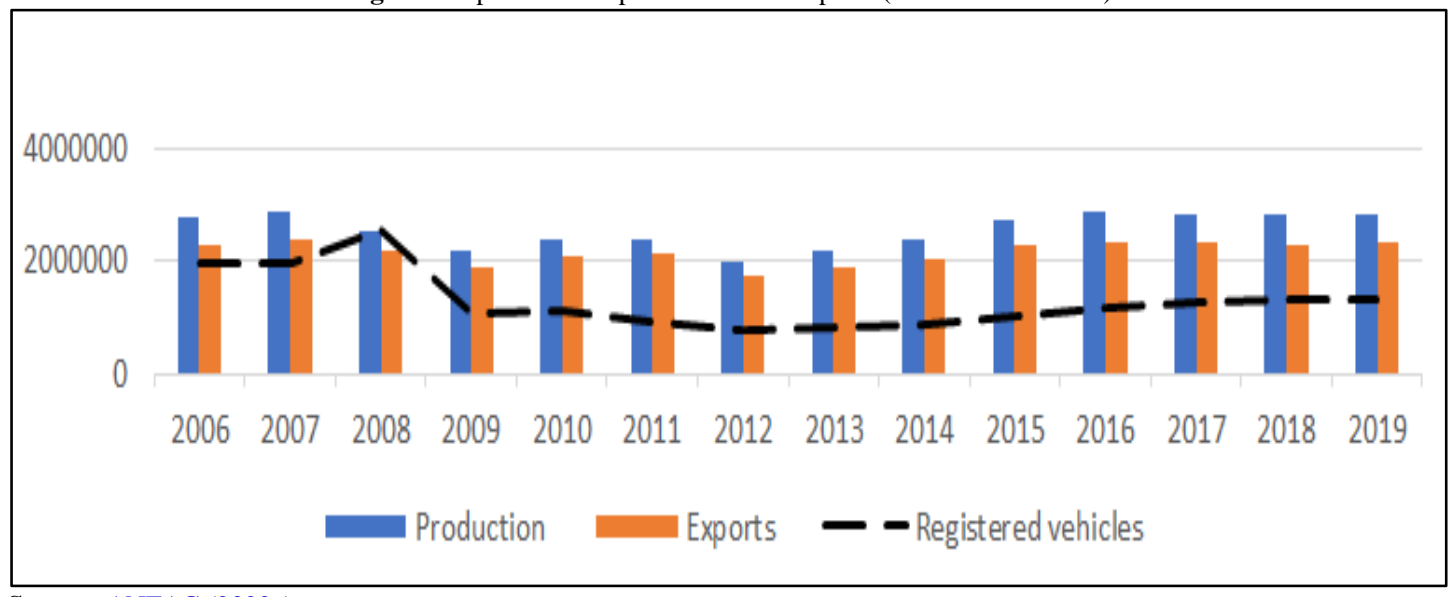

Source: ANFAC (2020a)

Figure-6. Historical evolution of the number of vehicles treated

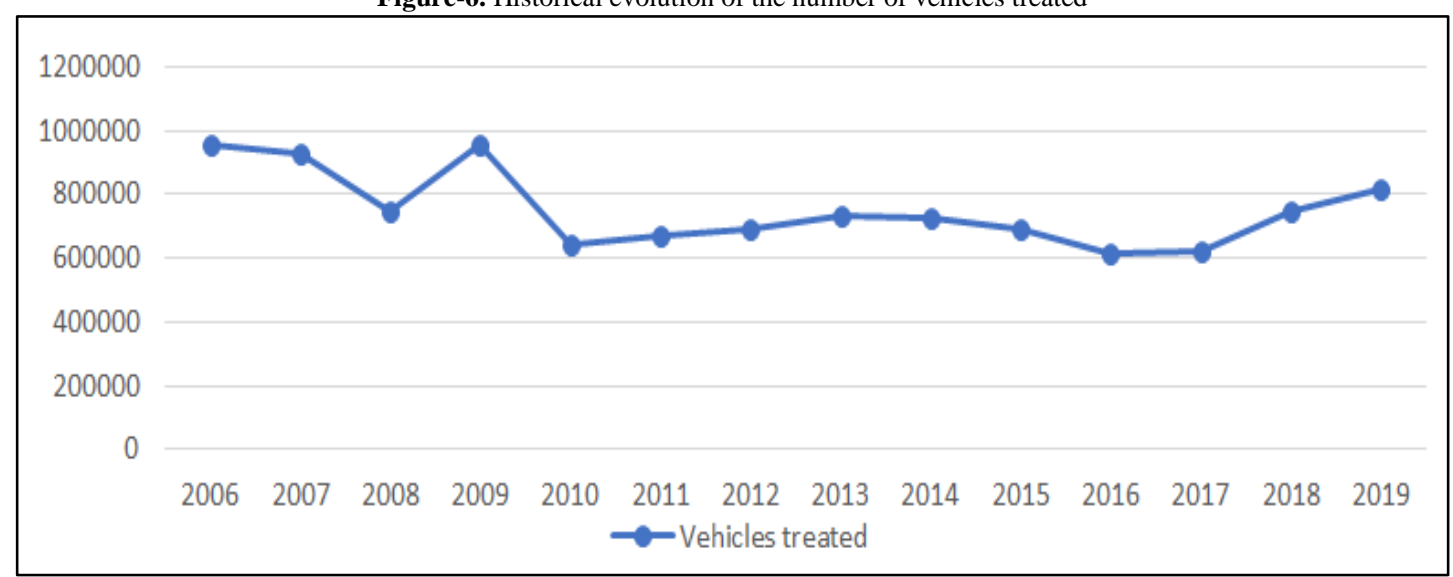

Source: SIGRAUTO (2020)

Figure-7. End-of-life vehicle recovery levels (\%)

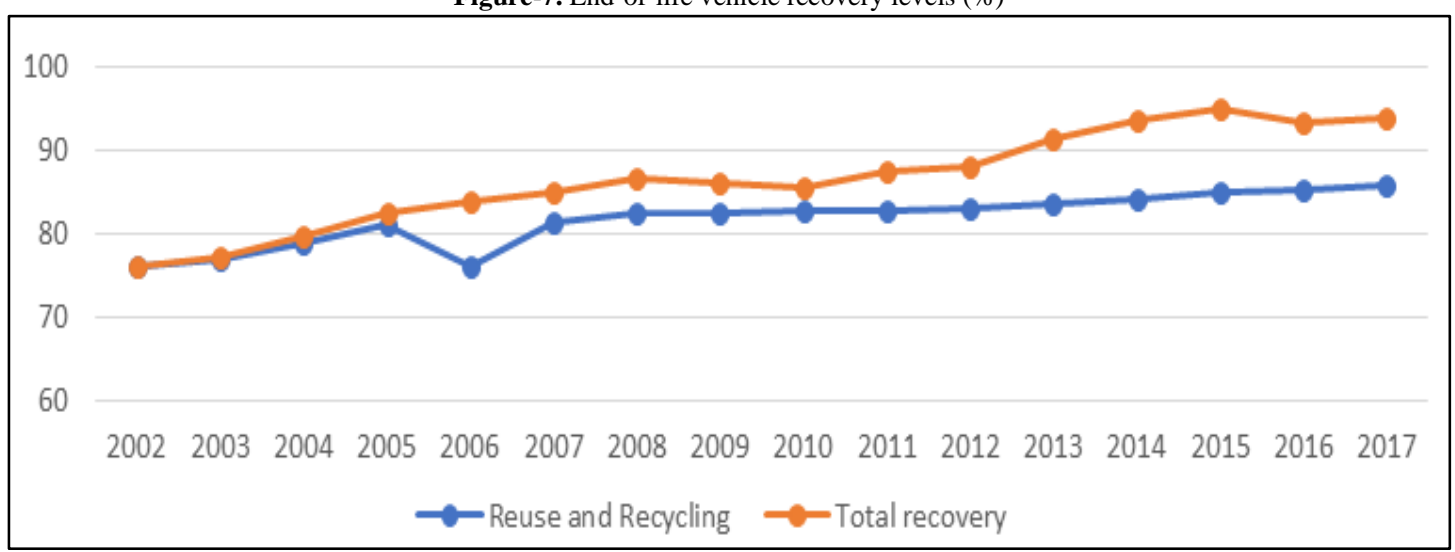

Source: SIGRAUTO (2020)

Figure-8. Average $\mathrm{CO}_{2}$ emissions from the registration of new vehicles

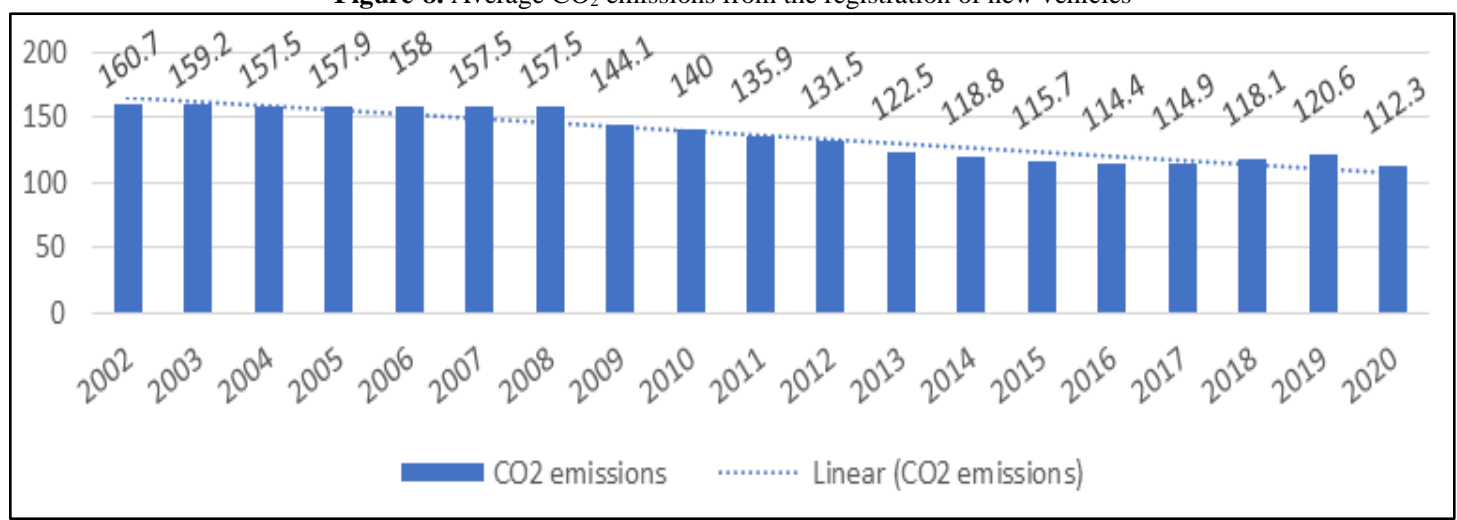

* First quarterly 2020

Source: (ANFAC (2020a)) 


\section{References}

Anderson, R. C. and Spiegelman, R. D. (1977). Tax policy and secondary material use. J. Env. Econ. Manag., 4: 6882. Available: https://doi.org/10.1016/0095-06967790016-X

Andersson, M., Söderman, M. L. and Sandén, B. A. (2019). Challenges of recycling multiple scarce metals: The case of Swedish ELV and WEEE recycling. Resources Policy, 63: 101-403. Available: https://doi.org/10.1016/j.resourpol.2019.101403

ANFAC (2020a). Annual report. Asociación española de fabricantes de automóviles y camiones. Available: https://anfac.com/categorias_publicaciones/informe-anual/

Arner, A. (2017a). Evaluación de las políticas de gestión de aceites usados: La responsabilidad ampliada del productor. Annals of Applied Economics, 32: 347-60. Available: https://www.researchgate.net/publication/323582950

Arner, A. (2017b). The Spanish waste oil market: A vector error correction model. International Journal of Energy Economics and Policy, 76: 1-10. Available: https://econpapers.repec.org/RePEc:eco:journ2:2017-06-1

Arner, A. (2018). The efficiency of extended producer responsibility in waste oil management with product differentiation (in Spanish). Estudios de Economía Aplicada, 36(3): 789-810. Available: http://dx.doi.org/10.25115/EEE.v36i3.2553

Arner, A., Barberán, R. and Mur, J., 2005. "La eficiencia de las políticas para promover la regeneración de aceites usados." In II Congreso Ibérico sobre Residuos Generados en la Industria. Madrid: Instituto para la Sostenibilidad de los Recursos.

Arner, A., Barberán, R. and Mur, J. (2006). La eficiencia de las políticas para promover la regeneración de aceites usados. XIII Encuentro de Economía Pública. Almería.

Atasu, A. and Subramanian, R. (2012). Extended producer responsibility for e-waste: Individual or collective producer responsibility. Prod. Oper. Manag., 21(6): 1042-59. Available: https://doi.org/10.1111/j.19375956.2012.01327.x

Atasu, A. and Van Wassenhove, L. (2012). An operations perspective on product take-back legislation for e-waste: Theory, practice, and research needs. Prod. Oper. Manag., 21(3): 407-22. Available: https://doi.org/5956.2011.01291.x

Atasu, A., Van Wassenhove, L. and Sarvary, M. (2009). Efficient take-back legislation. Prod. Oper. Manag., 18(3): 243-58. Available: https://doi.org/10.1111/j.1937-5956.2009.01004.x

Blomberg, J. and Hellmer, S. (2000). Short-run demand and supply elasticities in the West European market for secondary aluminum. Resour. Policy, 26: 39-50. Available: https://doi.org/10.1016/S0301-42070000015-5

Calcott, P. and Walls, M. (2005). Waste, recycling, and design for environment: Roles for markets and policy instruments. Resource and Energy Economics, 27(4): 287-305. Available: https://doi.org/10.1016/j.reseneeco.2005.02.001

Chen, W., Kucukyazici, B. and Saenz, M. J. (2019). On the joint dynamics of the economic and environmental performances for collective take-back systems. International Journal of Production Economics, 218: 22844. Available: https://doi.org/10.1016/j.ijpe.2019.04.028

Dinan, T. (1993). Economic efficiency effects of alternative policies for reducing waste disposal. Journal of Environmental Economics and Management, 25: 242-56. Available: https://doi.org/10.1006/jeem.1993.1046

Eichner, T. and Pethig, R. (2001). Product design and efficient management of recycling and waste treatment. Journal of Environmental Economics and Management, 41(1): 109-34. Available: https://doi.org/10.1006/jeem.2000.1126

Engle, R. F. and Granger, W. J. (1987). Co-integration and error correction: Representation, estimation, and testing. Econometrica, 552: 251-76. Available: https://doi.org/10.2307/1913236

Esenduran, G., Kemahhlioglu-Ziya, E. and Swaminathan, J. M. (2016). Take-back legislation: Consequences for remanufacturing and environment. Decision Sciences, 47(2): 219-56. Available: https://doi.org/10.1111/deci.12174

Esenduran, G., Atasu, A. and Van Wassenhove, L. (2019). Valuable e-waste: Implications for extended producer responsibility. IISE Transactions, $\quad$ 51(4): $382-96 . \quad$ Available: https://doi.org/10.1080/24725854.2018.1515515

Evans, M. and Lewis, A. C. (2005). Dynamic metals demand model. Resour. Policy, 30(1): 55-69. Available: https://doi.org/10.1016/j.resourpol.2004.12.003

Fisher, F. M., Cootner, P. H. and Baily, M. N. (1972). An econometric model of the world copper industry. Bell J. Econ. Manag. Sci., 3(2): 568-609. Available: https://doi.org/10.2307/3003038

Fleckinger, P. and Glachant, M. (2010). The organization of extended producer responsibility in waste policy with product differentiation. Journal of Environmental Economics and Management, 59(1): 57-66. Available: https://doi.org/10.1016/j.jeem.2009.06.002

Forslind, K. H. (2008). The effect of a premium in the Swedish car scrapping scheme: an econometric study. Environmental Economics and Policy Studies, 9: 43-55. Available: https://doi.org/10.1007/BF03353974

Fullerton, D. and Kinnaman, T. (1995). Garbage, recycling, and illicit burning or dumping. Journal of Environmental Economics and Management, 29(1): 78-91. Available: https://doi.org/10.1006/jeem.1995.1032

Fullerton, D. and Wu, W. (1998). Policies for green design. Journal of Environmental Economics and Management, 36(2): 131-48. Available: https://doi.org/10.1006/jeem.1998.1044 
Fullerton, D. and Wolverton, A. (2000). Two generalizations of a deposit-refund systems. American Economic Review, 90(2): 238-42. Available: https://doi.org/10.1257/aer.90.2.238

Geda, A., Ghosh, V., Karamemis, G. and Vakharia, A. (2020). Coordination strategies and analysis of waste management supply chain. Journal of Cleaner Production, 256, Number 120298: Available: https://doi.org/10.1016/j.jclepro.2020.120298

IDAE (2019). Support and funding, mobility and vehicles. Available: https://www.idae.es/ayudas-yfinanciacion/para-movilidad-y-vehiculos/beneficiarios-ayudas-pive-movele

Inghels, D., Dullaert, W., Raa, B. and Walther, G. (2016). Influence of composition, amount, and life spam of passenger cars on end-of-life vehicles waste in Belgium. A system dynamics approach. Transportation Research, Part A, 91: 80-104. Available: https://doi.org/10.1016/j.tra.2016.06.005

Kunz, N., Mayers, K. and Van Wassenhove, L. (2018). Stakeholder views on extended producer responsibility and the circular economy. California Management Review, 603: 45-70. Available: https://doi.org/10.1177/0008125617752694

Maddala, G. and Kim, I. (1999). Unit roots, cointegration, and structural change. Cambridge University Press: Cambridge.

Mazzanti, M. and Zoboli, R. (2006). Economic instruments and induced innovation: The European policies on endof-life vehicles. Ecological Economics, 58(2): 318-37. Available: https://doi.org/10.1016/j.ecolecon.2005.06.008

Nakamura, S., Kondo, Y., Matsubae, K., Nakajima, K., Tasaki, T. and Nagasaka, T. (2012). Quality-and dilution losses in the recycling of ferrous materials from end-of-life passenger cars: Input-output analysis under explicit consideration of scrap quality. Environ. Sci. Technol., 46(17): 9266-73. Available: https://doi.org/10.1021/es3013529

Novales, A. (2010). Econometría. McGraw-Hill: Madrid.

Palmer, K. and Walls, M. (1997). Optimal policies for solid waste disposal. Taxes, subsidies, and standards. Journal of Public Economics, 65(2): 193-205. Available: https://doi.org/10.1016/S0047-27279700028-5

Palmer, K. and Walls, M. (1999). Extended product responsibility: An economic assessment of alternative policies. Discussion paper 99-12. Resources for the Future: Washington, DC.

Palmer, K., Sigman, H., Walls, M., Harrison, K. and Puller, S. (1995). Cost of reducing solid waste: Comparing deposit-refunds, advance disposal fees, recycling subsidies, andrecycling rate standards. Discussion paper 95-33. Resources for the Future: Washington, DC.

Runkel, M. (2003). Product durability and extended producer responsibility in solid waste management. Environmental and Resource Economics, 24(2): 161-82. Available: https://doi.org/10.1023/A:1022800206337

SIGAUS (2018). Annual Report, 2017. Available: http://www.memoria2017.Sigaus.es/index.php/gestion-eficientede-recursos

SIGAUS (2019). Sustainability report, 2018. Available: www.memoria2018.Sigaus.es

SIGAUS (2020a). Annual report. Executive summary. Available: https://fr.zonesecure.net/18854/.ResumenEjecutivo2019_SIGAUS/\#page=1

SIGAUS (2020b). Sustainability Report, 2019. Available: www.memoria2019.Sigaus.es

Sigman, H. (1995). A comparison of public policies for lead recycling. Rand Journal of Economics, 26(3): $452-78$. Available: https://doi.org/10.2307/2555998

SIGRAUTO (2020). Annual Report, 2019. Available: http://www.sigrauto.com/pdf/Memoria2019.pdf

Slade, M. E. (1980). An econometric model of the US secondary copper industry: Recycling versus disposal. J. Env. Econ. Manag., 7(2): 123-41. Available: https://doi.org/10.1016/0095-06968090014-5

Suslow, V. (1986). Estimating monopoly behaviour with competitive recycling: An application to alcoa. $R A N D J$. Econ., 17(3): 389-403. Available: https://doi.org/10.2307/2555719

Toffel, M. W., Stein, A. and Lee, K. L. (2008). Extending producer responsibility: An evaluation framework for product take-back policies. SSRN Electronic Journal: Available: https://doi.org/10.2139/ssrn.1262335

Tsai, T. H., Wu, S. J. and Hwang, H. (2013). Waste recycling policies under extended producer responsibility: Takeback mandate versus deposit-refund. Global Journal of Economics, 2(2): Available: https://doi.org/10.1142/S2251361213500055

Walls, M. (2006). Extended producer responsibility and product design. RFF discussion paper 06-08. Resources for the Future: Baltimore.

Wang, W., Zhang, Y., Zhang, K., Bai, T. and Shang, J. (2015). A reward-penalty mechanism for closed-loop supply chains under responsibility-sharing and different power structures. Int. J. Production Economics, Part A, (170): 178-90. Available: https://doi.org/10.1016/j.ijpe.2015.09.003 